\title{
Biocatalytic activity of Aspergillus niger xylanase in paper pulp biobleaching
}

\author{
A. Sridevi ${ }^{1}$ A. Sandhya ${ }^{1}$ - G. Ramanjaneyulu ${ }^{2}$ - G. Narasimha ${ }^{3}$ P. Suvarnalatha Devi ${ }^{1}$
}

Received: 15 February 2016/Accepted: 1 August 2016/Published online: 11 August 2016

(c) The Author(s) 2016. This article is published with open access at Springerlink.com

\begin{abstract}
Xylanase is a hemicellulase enzyme that catalyses the hydrolysis of xylan to xylose which is widely used in processing of feed, pulp and paper. It is produced by many microorganisms especially filamentous fungi like Trichoderma and Aspergillus. A potential xylanolytic fungal isolate Aspergillus niger was isolated from forest soils of Tirumala, AP, India, and its crude enzyme was checked for its potential in paper bleaching. Under submerged fermentation, production of xylanase, cellulase, biomass, total protein and sugar released were analysed after 7 days of incubation at room temperature. Maximum enzyme activity was recorded on the fifth day of incubation, biomass after the seventh day, total protein and sugar released on the sixth day of incubation. Enzyme pretreatment of paper reduced 3.5 points in kappa number, 3.1 points increase in brightness and removal of chromophores and hydrophobic compounds. The FTIR and SEM analysis of enzyme-treated sample had shown modification in surface morphology and functional groups. These results clearly demonstrated that the xylanase produced by $A$. niger was effective as a pulp biobleaching agent which can be used on an industrial scale.
\end{abstract}

Keywords Biobleaching - Effluent characteristics · FTIR . SEM $\cdot$ Xylanase

\section{P. Suvarnalatha Devi}

drsuvarnapallipati@gmail.com

1 Department of Applied Microbiology, Sri Padmavathi Mahila Visvavidyalayam, Tirupati, AP, India

2 Department of Microbiology, Sri Krishnadevaraya University, Anantapur, AP, India

3 Applied Microbiology Lab, Department of Virology, Sri Venkateswara University, Tirupati, AP, India

\section{Introduction}

Considerable interest has been focused on the use of hydrolytic enzymes like xylanases that degrade xylan components in plant cell walls into simple sugars. Commercial applications of xylanases include pulp bleaching, food and animal feed industries, fuel, textile industries and in water management. They are required in bulk amounts and have significant application in paper and pulp industries as hydrolysis of xylan releases lignin from paper pulp and reduce usage of chemical bleaching agents. Throughout world pulp and paper mill industrial effluents contain toxic and harmful organic compounds as byproducts of pulping and bleaching processes. These effluents contain toxic heavy metals, lignin and its derivatives in addition to colour-imparting phenol and resinous compounds (Valls and Roncero 2009). Dark colour of unbleached pulp is due to the deposition of lignin and to remove colour one or more bleaching sequences like chlorine bleaching, oxidizing or reducing chemicals and alkaline extractions are needed (Khandeparkar and Bhosle 2007; Ziaie-shirkolaee et al. 2008). Due to use of these strong oxidants, chlorinated lignins and phenols are discharged into wastewaters. To substitute chlorine and to implement environmentally sound bleaching sequences by chlorine dioxide, hydrogen peroxide, oxygen, or ozone, among others can be used to get "totally chlorine-free" (TCF) bleaching. The drawback to introduce these environmentally sound technologies in pulp and paper industry is because it is difficult to attain high brightness degree as residual lignin and lignin-derived compounds that are more recalcitrant to degradation in TCF bleaching. To overcome these difficulties, enzymatic biobleaching using xylanases and laccases is an efficient alternative in many industrial applications. The ability of xylanases to facilitate the bleaching of kraft pulp was first 
reported in 1986 by the Finnish group led by Dr Lisa Viikari. Commercially supplied enzymes like cellulase and xylanase (Jeffries et al. 1994; Pala et al. 2004; Pathak et al. 2011) or lab-scale microbially produced enzymes reported by several researchers are applied to deink various types of papers (Gübitz et al. 1998; Vyas and Lachke 2003; Soni et al. 2010; Singh et al. 2012; Maity et al. 2012).

The application of enzymes like xylanases, cellulases or laccases in paper pulp bleaching is important as they reduce release of pollutants during bleaching and can also enhance the bleaching effect of chemical reagents by affording substantial savings (Valls and Roncero 2009). There are several reports on bioleaching using xylanases or fungal laccases either individually or in combination (Valls and Roncero 2009; Garg et al. 2011; Eugenio et al. 2010; Kapoor et al. 2007). Of late, scientists evinced interest in using filamentous fungi for production of xylanases and cellulases. Among the filamentous fungi, Aspergillus species are one of the most explored organisms. There are reports on xylanase production and application in pulp biobleaching process by many species of Aspergillus which include Aspergillus niger (Khonzue et al. 2011) A. terricola marchal and A. ochraceus (Michelin et al. 2010); A. niger, A. niveus and A. ochraceus (Betini et al. 2009); A. niveus RP05 and A. fumigatus RP04 (Peixoto-Nogueira et al. 2009); A. nidulans and A. awamori (Techapun et al. 2003); A. fumigatus (Savitha et al. 2007), and A. caespitosus (Sandrim et al. 2005). The results from the present study also agree with the existing reports and related results are discussed below. But studies regarding crude cellulase having xylanase activity for deinking and pulp biobleaching are very limited. In view of the industrial importance of xylanase, the present study is focused on evaluation of the extracellular xylanase produced by a potent fungal strain $A$. niger which is the first report of $A$. niger from Eastern Ghats and its ability in paper pulp biobleaching.

\section{Materials and methods}

\section{Microorganisms and maintenance}

The fungal strain A. niger used in this study was isolated from forest soil of Tirumala located in the eastern ghats of Andhra Pradesh, India, on potato dextrose agar medium. The stock cultures were maintained at $4{ }^{\circ} \mathrm{C}$ on slants of the same medium and deposited in our microbiology laboratory. Spore suspension $\left(2 \times 10^{6}\right.$ count $)$ was inoculated into a 250-ml Erlenmeyer flask containing $100 \mathrm{ml}$ of MYG fermentation medium (glucose, $3 \mathrm{~g}$; yeast extract, 0.8; $\mathrm{K}_{2} \mathrm{HPO}_{4}, 0.4 ; \mathrm{MgSO}_{4} \cdot 7 \mathrm{H}_{2} \mathrm{O}, 0.2 ; \mathrm{pH}, 7.0$ and incubated at $28 \pm 2{ }^{\circ} \mathrm{C}$ at $180 \mathrm{rpm}$ for 7 days in a rotary shaking incubator.

\section{Screening}

Screening of xylanase producing fungal strain was done in our laboratory using PDA medium with $1 \%$ birchwood xylan. Five mm disc of the 4-day culture was placed the medium and incubated at $37{ }^{\circ} \mathrm{C}$. After 3 days of incubation, the plates were stained with $1 \%$ Congo Red and destained with $1 \mathrm{M} \mathrm{NaCl}$. The best xylanase producer was selected for further studies based on the extent of formation of clear zone.

\section{Determination of xylanase activity}

After incubation, the cultured broth was centrifuged (10,000 rpm) using a high-speed centrifuge for $15 \mathrm{~min}$ and the supernatant was used for enzyme assay. Xylanase activity was determined by the method of Bailey et al. (1992). Reaction mixture consisting $0.5 \mathrm{ml}$ of culture filtrate with $0.5 \mathrm{ml}$ of $1 \%$ birchwood xylan [prepared in citrate buffer $(0.05 \mathrm{M}, \mathrm{pH} 5.0)$ ] was incubated for $15 \mathrm{~min}$ at $50{ }^{\circ} \mathrm{C}$. After incubation the reaction was ceased by the addition of $1.5 \mathrm{ml}$ of 3,5 dinitrosalicylic acid (Miller 1959) and heated for $10 \mathrm{~min}$ in boiling water bath. After cooling the reducing sugars liberated were measured spectrophotometrically at $540 \mathrm{~nm}$. One unit of enzyme activity was defined as the amount of enzyme required to liberate $1 \mathrm{~mol}$ of reducing sugars per minute.

\section{Assay of cellulase}

Estimation of cellulase activity was tested by Dinitrosalicylic acid (DNS) reagent (Miller 1959) which involves estimation of released reducing sugars from carboxy methyl cellulose (CMC) in $0.05 \mathrm{M}$ phosphate buffer. Crude enzyme was added to $0.5 \mathrm{ml}$ of $1 \% \mathrm{CMC}$ in $0.05 \mathrm{M}$ phosphate buffer and incubated at $50{ }^{\circ} \mathrm{C}$ for $30 \mathrm{~min}$. After incubation, the reaction was halted by the addition of $1.5 \mathrm{ml}$ of DNS reagent and boiled at $100{ }^{\circ} \mathrm{C}$ in a water bath for $10 \mathrm{~min}$. Released sugars were estimated by measuring absorbance at $540 \mathrm{~nm}$. One unit of enzyme activity is expressed as the amount of enzyme, which is required to release $1 \mathrm{~mol}$ of glucose per minute under standard assay conditions.

\section{Characterization of paper pulp}

Paper pulp was prepared by soaking printing paper waste in distilled water for $2 \mathrm{~h}$, macerated in a domestic mixer and was oven-dried at $50{ }^{\circ} \mathrm{C}$. Enzymatic bleaching of paper pulp was performed at a consistency of $3 \%(\mathrm{w} / \mathrm{v})$ and was mixed with crude enzyme (xylanase, 20-100 U/g of pulp) and incubated at $50{ }^{\circ} \mathrm{C}$ for $2 \mathrm{~h}$. The treated pulp was filtered and the filtrate was used for biochemical analysis. 
Residual pulp was washed to prepare hand sheets by pressing between two stainless steel plates to form hand sheets and were dried at $50{ }^{\circ} \mathrm{C}$ for $3 \mathrm{~h}$. A control was maintained without enzyme. The brightness of the pulp was determined according to the method of Jordan and Popson (1994). Chromophores, hydrophobic compounds of filtrate were measured at 237 and $465 \mathrm{~nm}$ and reducing sugars were determined by DNS method (Miller 1959).

\section{Scanning electron microscopic analysis}

Morphological differences in pulp before and after the enzyme pretreatment were visualized by JEOL JSM-5600 scanning electron microscope. Images were taken at a magnification of $150 \times$. Specimens to be coated were mounted on a conductive tape and coated with gold palladium using a JEOL-JFC-1200 fine coater and observed using a voltage of $25 \mathrm{kV}$.

\section{FTIR analysis}

FTIR was recorded on Perkin-Elmer IR instrument to thoroughly understand the morphological changes in paper pulp. Functional groups before and after enzymatic treatment were characterized and spectra of both samples presented.

\section{Results and discussion}

The isolates that had produced clear zone around colonies on MYG and CMC media after staining with Congo Red followed by destaining were recorded positive for xylanase and cellulase enzymes. Of them, one of the potential isolates (S5) was checked for its ability in quantitative secretion of hydrolytic enzymes and bioleaching of paper pulp. Preliminary microscopic examination of the isolate led to its identification as Aspergillus species and its screening is depicted in Fig. 1. The quantitative screening of the isolate and its enzyme activity is shown in Table 1. Enzyme production assays revealed that the isolate A. niger is both cellulolytic and xylanolytic. It was observed that maximum production of xylanase and cellulase occurred on the 5th day of incubation, but the present strain secreted higher xylanase $(453.9 \mathrm{U} / \mathrm{ml})$ when compared to cellulase (22.7 U/ml). Biomass, soluble sugar and protein secretion contents are shown in Table 2. Growth of fungal strain increased with incubation and reached maximum on the 7 th day of incubation. Secreted total protein and sugar were found to be maximum after 6 days of incubation.

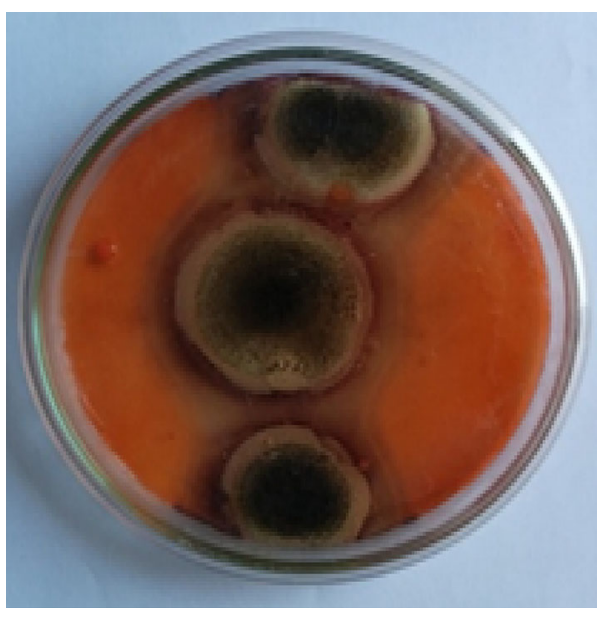

Fig. 1 Isolation and screening of A. niger for production of xylanase

Table 1 Quantitative screening for xylanase production by A. niger

\begin{tabular}{llll}
\hline $\begin{array}{l}\text { Day of } \\
\text { incubation }\end{array}$ & $\begin{array}{l}\text { Xylanase activity } \\
(\mathrm{U} / \mathrm{mL})\end{array}$ & $\begin{array}{l}\text { Cellulase activity } \\
(\mathrm{U} / \mathrm{ml})\end{array}$ & $\begin{array}{l}\text { Change in } \\
\mathrm{pH}\end{array}$ \\
\hline 2 & 12.6 & 3.5 & 3.1 \\
3 & 64.8 & 10.3 & 3.7 \\
4 & 121.7 & 17.5 & 4.2 \\
5 & 453.9 & 22.7 & 4.9 \\
6 & 397.3 & 15.2 & 5.3 \\
7 & 276.3 & 9.4 & 5.5 \\
\hline
\end{tabular}

Table 2 Biomass, total protein and total sugar content of $A$. niger at different days of incubation

\begin{tabular}{llll}
\hline $\begin{array}{l}\text { Day of } \\
\text { incubation }\end{array}$ & $\begin{array}{l}\text { Biomass }(\mathrm{mg} / \\
\text { flask })\end{array}$ & $\begin{array}{l}\text { Total protein } \\
(\mu \mathrm{g} / \mathrm{ml})\end{array}$ & $\begin{array}{l}\text { Total sugar }(\mu \mathrm{g} / \\
\mathrm{ml})\end{array}$ \\
\hline 2 & 240 & 176 & 262 \\
3 & 478 & 386 & 312 \\
4 & 651 & 493 & 597 \\
5 & 824 & 674 & 768 \\
6 & 946 & 896 & 924 \\
7 & 1043 & 812 & 845 \\
\hline
\end{tabular}

\section{Molecular characterization}

The 18S rRNA sequence was determined to investigate the relatedness of this strain to other species. Comparison of the sequence of the strain with the closest described species showed a $100 \%$ similarity with A. niger and the strain was deposited in the NCBI nucleotide sequence databases with an accession number of KT727925. The phylogenetic tree was constructed as shown in Fig. 2. 


\section{Phylogram}

Branch length: 0 Cladogram $\bigcirc$ Real

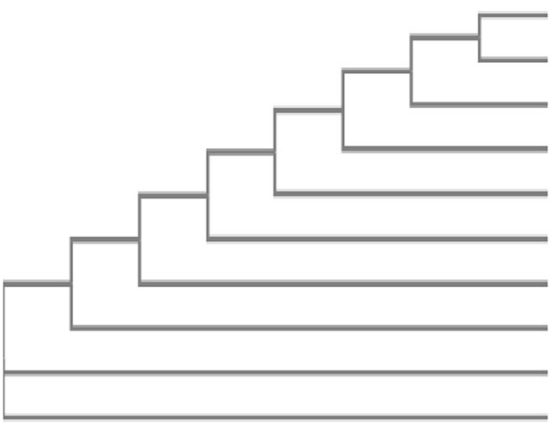

gi|270303619_Aspergillus 0 gi|270303625_Aspergillus 0 $\$ 50.00965$ gi|199595091_Aspergillus 0 gi|161408454_Aspergillus 0 gi|307088981_Aspergillus 0 gi|149212422_Aspergillus 0 gi|133752976_Aspergillus 0 gi|319429236_Aspergillus 0 gi|320584278_Aspergillus 0

Fig. 2 Phylogenetic tree of potential isolate constructed using NCBI

\section{Enzymatic characterization of paper pulp}

Xylanase and laccase enzymes may reduce hexenuronic acid (HexA) content of pulp by releasing xylans with xylanases, or direct oxidation with laccases or via yet unknown mechanism (Cadena et al. 2010). Hexenuronic acids that formed during alkaline cooking of pulp increase kappa number and reverse brightness and show adverse effects on pulp bleaching (Fillat et al. 2011). In support of this, the pulp bleaching potential of the crude xylanase from A. niger was evaluated by estimation of kappa number, brightness and reducing sugars. After enzyme treatment kappa number decreased and brightness of the pulp increased. Treatment after $1 \mathrm{~h}$ with $60 \mathrm{U} / \mathrm{g}$ dry pulp decreased 3.5 points in kappa number when compared to control. Kappa number is an indication of the lignin content or bleach ability of paper pulp. Further it has shown reduction in kappa number as well as 3.1 points increase in brightness after the enzyme treatment. Measurement of chromophores and hydrophobic compounds absorbance at 237 and $465 \mathrm{~nm}$ expected releasing from lignin and hemicelluloses (Table 3). Hemicellulases have also been proposed to cleave hemicellulose bonds near points of

Table 3 Properties of untreated and xylanase-treated pulp

\begin{tabular}{lcl}
\hline Parameter & Untreated & $\begin{array}{l}\text { Xylanase treated } \\
(60 \mathrm{U} / \mathrm{g})\end{array}$ \\
\hline Kappa number & 23.3 & 19.8 \\
Brightness (ISO units) & 38.7 & 41.8 \\
Chromophoric compounds $\left(\lambda_{237}\right)$ & 0.193 & 0.689 \\
Hydrophobic compounds $\left(\lambda_{465}\right)$ & 0.093 & 0.213 \\
Reducing sugar $(\mathrm{mg} / \mathrm{g})$ & 1.14 & 2.23 \\
\hline
\end{tabular}

attachment between lignin and hemicellulose and it is possible that this leads to the improved solubilization of lignin.

It was observed that with increase in time and increasing enzyme concentration there was 3.9 points decrease in the kappa number after $3 \mathrm{~h}$ of treatment and the brightness improved to 2.2, 2.8 and 3.1 points following treatment with 10,20 and $40 \mathrm{U} / \mathrm{g}$ dry pulp, respectively, during $2 \mathrm{~h}$ of treatment (Guimarães et al. 2013). Using xylanase of $A$. japonicus $(40 \mathrm{U} / \mathrm{g}$ dry pulp/2 h) the brightness of pulp improved 3.1 points, while the xylanase of $A$. ochraceus ( $35 \mathrm{U} / \mathrm{g}$ dry pulp/2 h) improved the brightness just 2.0 points (Betini et al. 2009). Free reducing sugar released after enzyme treatment from pulp was found to be $1.09 \mathrm{mg} /$ $\mathrm{g}$ in this study. The effectiveness of enzyme pretreatment on pulp and release of reducing sugars was evaluated by other researchers like $33 \mathrm{mg}$ of reducing sugar per gram of wheat straw pulp with $5 \mathrm{U} / \mathrm{g}, 25.78 \mathrm{mg} / \mathrm{g}$ of pulp after $3 \mathrm{~h}$ of incubation, $416 \mathrm{mg} / \mathrm{g}$ of pulp with purified xylanase of $150 \mathrm{U} / \mathrm{g}$ of pulp (Guimarães et al. 2013; Li et al. 2006; Bissoon et al. 2002). Even though release of reducing sugar is maximum in other reports this study limited in enzyme dose in bleaching process because enzyme concentration and loading is important in pulp bleaching as higher enzyme dose may damage to pulp fibres (Jurasek and Paice 1986).

Reduction in kappa number, brightness increase and release of reducing sugars showed the potentiality of this fungal strain and its crude xylanase effect in paper and pulp industry. The FTIR measurements of paper pulp were carried out to identify the differences before and after enzyme pretreatment. The FTIR spectrum (Fig. 3a, b) showed peaks at different wavelengths corresponding to structural changes. The broad peak at $3000-3333 \mathrm{~cm}^{-1}$ indicated the $\mathrm{O}-\mathrm{H}$ stretching while the band at $2360 \mathrm{~cm}^{-1}$ is due to $-\mathrm{OH}$ stretching of carboxylic acid in enzymatic treated pulp. The band at 1730 is due to $\mathrm{C}=\mathrm{O}$ stretch of hemicelluloses and from 1636 to $1236 ; 1180$ to $600 \mathrm{~cm}^{-1}$ is $\mathrm{C}-\mathrm{H}$ and $\mathrm{C}-\mathrm{O}$ bendings hemicellulose, respectively. Lignin and hemicellulose deformations were clear by observing above results in the treated pulp. A spectrum in FTIR is based on the infrared radiation absorption at frequencies that match those of the normal modes of vibration within the macromolecule. These absorption features are characteristics of the molecular configuration, sequencing and conformation. The intensity of an absorption band is related to the dipole moment change associated with the molecular vibration. The observed IR frequencies are given in Table 4. The characterization and interpretation of various functional groups are shown in Fig. 3a, b and Table 4. SEM images had also shown change in morphology of pulp 
Fig. 3 a Untreated paper pulp FTIR spectra. b Enzyme-treated paper pulp

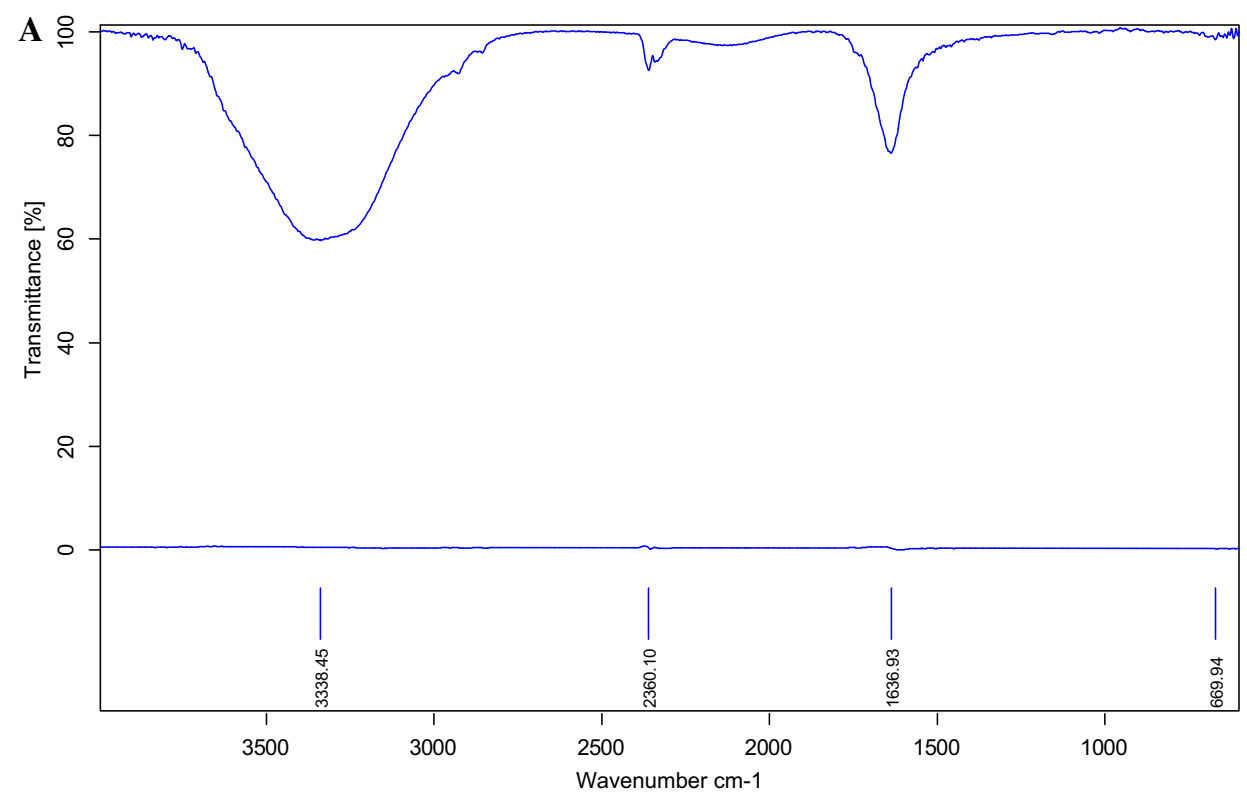

\begin{tabular}{|llcl|l|}
\hline C:IProgram FilesIOPUS_65IMEASITTO.1 & TТO & Instrument type and / or accessory & $10 / 01 / 2015$ \\
\hline C:IProgram FilesIOPUS_65IMEASITTO.1 & TTO & Instrument type and / or accessory & $10 / 01 / 2015$ \\
\hline
\end{tabular}

B

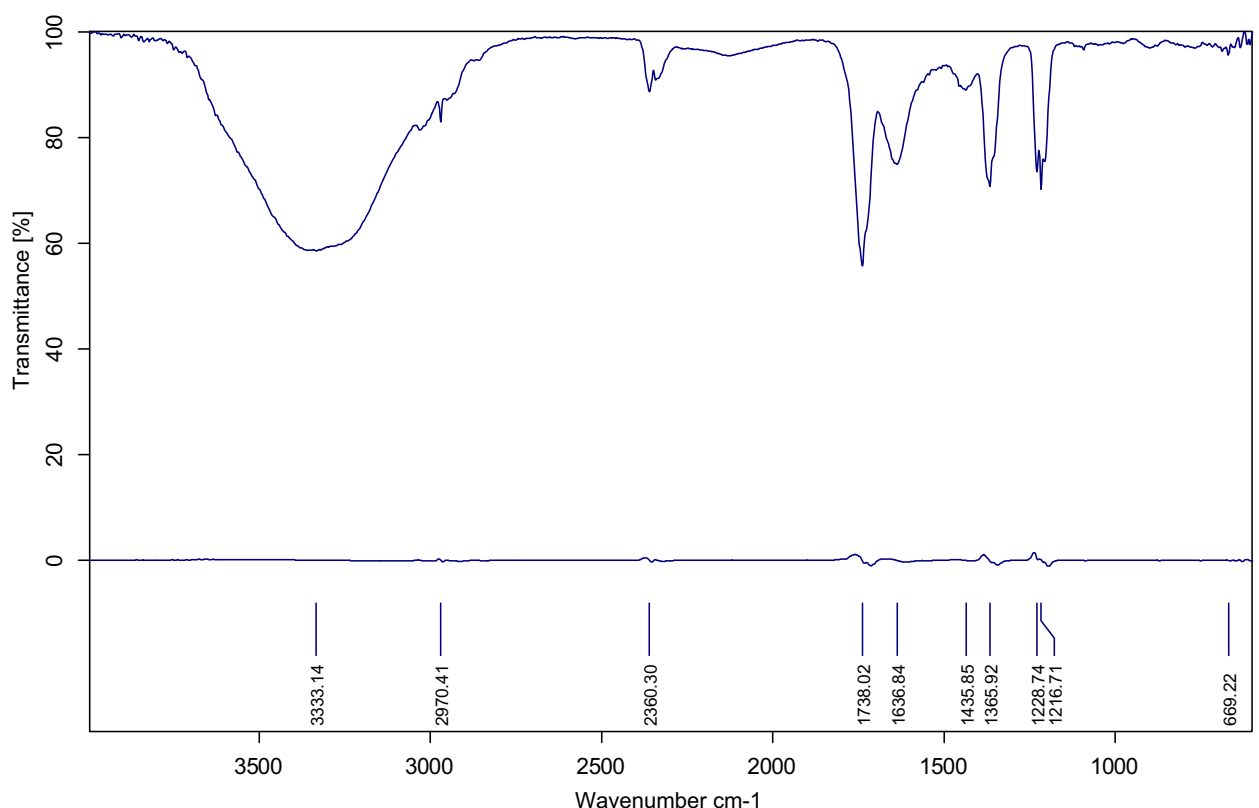

\begin{tabular}{|lll|l|}
\hline C:IProgram FilesIOPUS_65IMEASI6(1).0 & $6(1)$ & Instrument type and / or accessory & $10 / 01 / 2015$ \\
\hline C:IProgram FilesIOPUS_65IMEASI6(1).0 & $6(1)$ & Instrument type and / or accessory & $10 / 01 / 2015$ \\
\hline
\end{tabular} 
Table 4 Characterization and interpretation of various functional groups

\begin{tabular}{|c|c|c|c|}
\hline \multicolumn{2}{|l|}{ Untreated } & \multicolumn{2}{|l|}{ Enzyme-treated } \\
\hline $\begin{array}{l}\text { Absorption ranges } \\
\text { Ranges }\left(\mathrm{cm}^{-1}\right)\end{array}$ & Type of vibration & $\begin{array}{l}\text { Absorption ranges } \\
\text { Ranges }\left(\mathrm{cm}^{-1}\right)\end{array}$ & Type of vibration \\
\hline 3333.45 & $-\mathrm{OH}$ stretching of hydrogen-bonding & 3333.14 & $-\mathrm{OH}$ stretching of hydrogen-bonding \\
\hline 2925.80 & $=\mathrm{C}-\mathrm{H}$ stretch & 2970.41 & - \\
\hline 2360.10 & $\begin{array}{l}\mathrm{OH} \text { asymmetrical stretching } \\
\text { vibration in carboxylic acids }\end{array}$ & 2360.30 & $\mathrm{OH}$ asymmetrical stretching vibration in carboxylic acids \\
\hline 2138 & - & 1738.02 & $\mathrm{CH}$ asymmetrical stretching vibration in $\mathrm{CH} 3, \mathrm{CH} 2$ \\
\hline 1636.93 & $\mathrm{C}=\mathrm{O}$ stretch & $\begin{array}{l}1636.84 \\
1435.85\end{array}$ & $\begin{array}{l}\mathrm{C}=\mathrm{O} \text { stretch, amides, } \mathrm{C}=\mathrm{C} \text { stretching } \\
\mathrm{C}=\mathrm{H} \text { stretching }\end{array}$ \\
\hline 1312.60 & - & 1365.92 & $\mathrm{C}=\mathrm{O}$ stretch vibration in syringyl ring \\
\hline 1048.06 & $\mathrm{C}-\mathrm{H}$ & $\begin{array}{l}1228.74 \\
1216.71\end{array}$ & $\mathrm{C}-\mathrm{O}$ stretching \\
\hline 1183.74 & - & 1183.74 & -COO- (carboxylate ion) groups \\
\hline 669.94 & $\mathrm{~N}-\mathrm{O}$ stretch & 669.92 & $\mathrm{~N}-\mathrm{O}$ stretch \\
\hline 647.76 & - & 647.76 & $\mathrm{C}-\mathrm{O}$ \\
\hline 616 & - & 616 & $\mathrm{C}=\mathrm{O}$ stretch \\
\hline
\end{tabular}
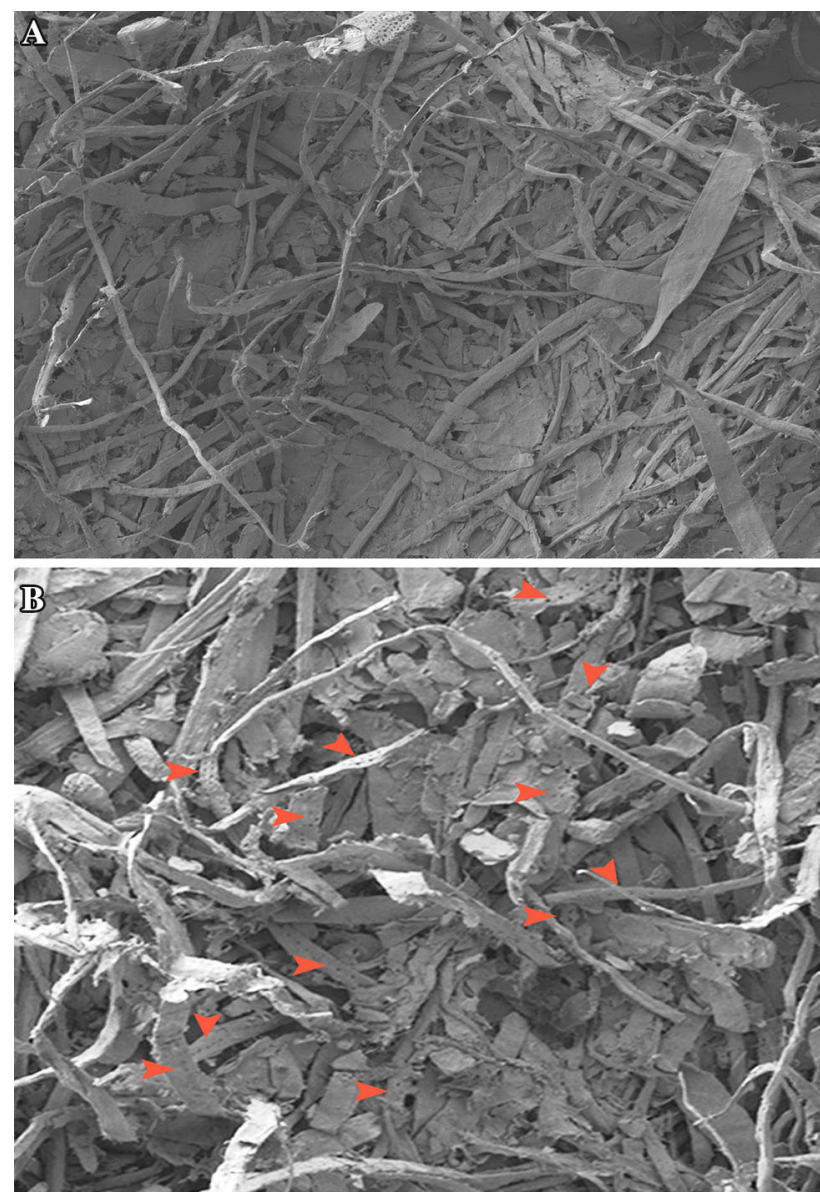

Fig. 4 a Untreated paper pulp SEM image. b Enzyme-treated paper pulp fibres with breaking and appearance of pores in fibres (Fig. 4a, b).

\section{Conclusions}

Maximum yield of xylanase was produced by A. niger used in this study after 5 days of incubation when $1 \%$ xylan was used as the substrate. Moreover, the strain has also exhibited ability to produce cellulase in low quantities. Crude enzyme dose had reduced kappa number and increased brightness of paper pulp. Change in functional groups identified by FTIR and surface morphological changes in fibres of pulp obtained by SEM results had confirmed that the present strain A. niger is effective in pulp biobleaching and can be explored on an industrial scale.

Acknowledgments The authors acknowledge UGC, New Delhi, for their financial assistance in the form of fellowship to carry out this work.

\section{Compliance with ethical standards}

Conflict of interest Authors have no conflict of interest.

Open Access This article is distributed under the terms of the Creative Commons Attribution 4.0 International License (http:// creativecommons.org/licenses/by/4.0/), which permits unrestricted use, distribution, and reproduction in any medium, provided you give appropriate credit to the original author(s) and the source, provide a link to the Creative Commons license, and indicate if changes were made. 


\section{References}

Bailey MJ, Biely P, Poutanen K (1992) Interlaboratory testing of methods for assay of xylanase activity. J Biotechnol 23:257-270

Betini JHA, Michelin M, Peixoto-Nogueira SC, Jorge JA, Terenzi HF et al (2009) Xylanases from Aspergillus niger, Aspergillus niveus and Aspergillus ochraceus produced under solid-state fermentation and their application in cellulose pulp bleaching. Bioprocess Biosyst Eng 32:819-824

Bissoon S, Christov L, Singh S (2002) Bleach boosting effects of purified xylanase from Thermomyces lanuginosus SSBP on bagasse pulp. Process Biochem 37:567

Cadena EM, Vidal T, Torres AL (2010) Influence of the hexenuronic acid content on refining and ageing in eucalyptus TCF pulp. Bioresour Technol 101(10):3554-3560

Eugenio ME, Santos SM, Carbajo JM, Martin JA, Martín-Sampedro R, Gonzalez AE, Villar JC (2010) Kraft pulp biobleaching using an extracellular enzymatic fluid produced by Pycnoporus sanguineus. Bioresour Technol 101(6):1866-1870

Fillat A, Roncero MB, Vidal T (2011) Assessing the use of xylanase and laccases in biobleaching stages of a TCF sequence for flax pulp. J Chem Technol Biotechnol 86(12):1501-1507

Garg G, Dhiman SS, Mahajan R, Kaur A, Sharma J (2011) Bleachboosting effect of crude xylanase from Bacillus stearothermophilus SDX on wheat straw pulp. New Biotechnol 28(1):58-64

Gübitz GM, Mansfield SD, Böhm D, Saddler JN (1998) Effect of endoglucanases and hemicellulases in magnetic and flotation deinking of xerographic and laser-printed papers. J Biotechnol 65:209-215

Guimarães NCA, Sorgatto M, Peixoto-Nogueira SC, Betini JHA, Zanoelo FF et al (2013) Xylanase production from Aspergillus japonicus var aculeatus: production using agroindustrial residues and biobleaching effect on pulp. J Biocatal Biotransformation $2: 1$

Jeffries TW, Klungness JH, Marguerite S, Cropsey KR (1994) Comparison of enzyme-enhanced with conventional deinking of xerographic and laser-printed paper. TAPPI J 77:173-179

Jordan BD, Popson SJ (1994) Measuring the concentration of residual ink in recycled newsprint. J Pulp Paper Sci 20:161-167

Jurasek L, Paice M (1986) Pulp, paper and biotechnology. Chem Tech 16:360-365

Kapoor M, Kapoor RK, Kuhad RC (2007) Differential and synergistic effects of xylanase and laccase mediator system (LMS) in bleaching of soda and waste pulps. J Appl Microbiol 103(2):305-317

Khandeparkar R, Bhosle NB (2007) Application of thermo alkalophilic xylanase from Arthrobacter sp. MTCC 5214 in biobleaching of kraft pulp. Bioresour Technol 98:897-903

Khonzue P, Laothanachareon T, Rattanaphan N, Tinnasulanon P, Apawasin $S$ et al (2011) Optimization of xylanase production from Aspergillus niger for biobleaching of eucalyptus pulp. Biosci Biotechnol Biochem 75:1129-1134
Li L, Tian H, Cheng Y, Jiang Z, Yang S (2006) Purification and characterization of a thermostable cellulase-free xylanase from the newly isolated Paecilomyces thermophila. Enzyme Microb Technol 38:780-787

Maity C, Ghosh K, Halder SK, Jana A, Adak A, Mohapatra PKD (2012) Xylanase isozymes from the newly isolated Bacillus sp. CKBx1D and optimization of its deinking potentiality. Appl Biochem Biotechnol 167:1208-1219

Michelin M, Peixoto-Nogueira SC, Betini JH, da Silva TM, Jorge JA et al (2010) Production and properties of xylanases from Aspergillus terricola Marchal and Aspergillus ochraceus and their use in cellulose pulp bleaching. Bioprocess Biosyst Eng $33: 813-821$

Miller GL (1959) Use of dinitrosalicylic acid reagent for determination of reducing sugar. Anal Chem 31:426-429

Pala H, Mota M, Gama FM (2004) Enzymatic versus chemical deinking of non-impact ink printed paper. J Biotechnol 108:79-89

Pathak P, Bhardwaj NK, Singh AK (2011) Optimization of chemical and enzymatic deinking of photocopier waste paper. Bioresources 6:447-463

Peixoto-Nogueira SC, Michelin M, Betini JHA, Jorge JA, Terenzi HF et al (2009) Production of xylanase by aspergilli using alternative carbon sources: application of the crude extract on cellulose pulp biobleaching. J Ind Microbiol Biotechnol 36:149-155

Sandrim VC, Rizzatti ACS, Terenzi HF, Jorge JA, Milagres AMF et al (2005) Purification and biochemical characterization of two xylanases produced by Aspergillus caespitosus and their potential for kraft pulp bleaching. Process Biochem 40:1823-1828

Savitha S, Sadhasivam S, Swaminathan K (2007) Application of Aspergillus fumigatus xylanase for quality improvement of waste paper pulp. Bull Environ Contam Toxicol 78:217-221

Singh A, Yadav RD, Kaur A, Mahajan R (2012) An ecofriendly cost effective enzymatic methodology for deinking of school waste paper. Bioresour Technol 120:322-332

Soni R, Nazir R, Chadha BS (2010) Optimization of cellulase production by a versatile Aspergillus fumigatus fresenius strain (AMA) capable of efficient deinking and enzymatic hydrolysis of Solka floc and bagasse. Ind Crops Prod 31:277-283

Techapun C, Poosaran N, Watanabe M, Sasaki K (2003) Thermostable and alkaline-tolerant microbial cellulase-free xylanases produced from agricultural wastes and the properties required for use in pulp bleaching bioprocesses: a review. Process Biochem 38:1327-1340

Valls C, Roncero MB (2009) Using both xylanase and laccase enzymes for pulp bleaching. Bioresour Technol 100:2032-2039

Vyas S, Lachke A (2003) Biodeinking of mixed office waste paper by alkaline active cellulase from alkalotolerant Fusarium sp. Enzyme Microb Technol 32:236

Ziaie-shirkolaee Y, Talibizadeh A, Soltanali S (2008) Comparative study on application of $T$. lanuginos us SSBP xylanase and on commercial xylanase on biobleaching of non wood pulps. Bioresour Technol 99:7433-7437 